DOI: $10.17516 / 1997-1370-0679$

УДК 332.142

\title{
Research on the Issues of Economic Growth Centres' Establishment in the South of the Angara-Yenisei Macroregion
}

\author{
Elena A. Bryukhanovaa, Valery S. Efimov \\ and Nikolay G. Shishatsky*a \\ anstitute of Economics and Industrial Engineering of SB RAS \\ Krasnoyarsk, Russian Federation \\ ${ }^{b}$ Siberian Federal University \\ Krasnoyarsk, Russian Federation
}

Received 29.06.2020, received in revised form 29.08.2020, accepted 09.11.2020

\begin{abstract}
The article considers the peculiarities and conditions for the implementation of large investment projects and the possibility of forming regional centres for promising economic growth on this basis. The authors have analysed large investment projects aimed at developing the mineral and raw materials sector in the southern regions of the Angara-Yenisei macroregion, and assessed the impact of projects on indicators of socioeconomic development of territories. The article shows that the project approach aimed at implementing individual investment projects and creating growth points in the mineral and raw materials sector should be supplemented by measures aimed at developing the territorial infrastructure, stimulating small and medium-sized businesses and improving all aspects of life support for the population.
\end{abstract}

Keywords: Angara-Yenisei macroregion, centre for promising economic growth, clusters, large investment project, integrated socio-economic development.

The reported study was funded by Russian Foundation for Basic Research, Government of Krasnoyarsk Territory, Krasnoyarsk Regional Fund of Science, project number 19410-240003 "Substantiation of the priorities of the accelerated social and economic development of regions of the Yenisei Siberia (on the example of the southern territories of Krasnoyarsk Krai, the Republic of Khakassia and the Republic of Tyva)".

Research area: economics.

Citation: Bryukhanova, E.A., Efimov, V.S., Shishatsky, N.G. (2020). Research on the issues of economic growth centres' establishment in the south of the Angara-Yenisei macroregion. J. Sib. Fed. Univ. Humanit. Soc. Sci., 13(11), 1736-1745. DOI: 10.17516/1997-1370-0679.

\footnotetext{
(C) Siberian Federal University. All rights reserved

* Corresponding author E-mail address: eab@ksc.krasn.ru; efimov.val@gmail.com; nik@ksc.krasn.ru ORCID: 0000-0002-0768-4770 (Bryukhanova); 0000-0001-8256-5512 (Shishatskiy)
} 


\section{Introduction}

The raw material orientation of industry and export is one of the main disadvantages of the modern economic development of Russia. At the same time, it is the raw materials industries, in combination with the necessary transport, energy and social infrastructure, that create favourable opportunities for the formation of new centres and points of economic growth in a number of regions of the country, primarily in Siberia and the Far East.

The features of the potential and growth factors of the Siberian and Eastern regions determine the choice of a package of strategic projects that implement the priorities of their economic development. If in the regions of the European part of Russia one can count on an inflow of private investment in a wide variety of industries (directed toward both to the domestic and foreign markets), then in the regions of the Asian part of the country the spectrum of possible industries is much narrower. These include, first of all, the development of natural resources.

The most important factor constraining the economic development of the resource regions of the country as a whole and the implementation of existing large-scale investment projects in particular is the insufficient level of development of transport and energy infrastructure, as well as the weak integration of extractive industries into value chains based on deep processing of the extracted raw materials.

In many respects, it is for this reason that most of the regional points of growth and socio-economic development outlined by the constituent entities of the Russian Federation have not yet been supported either by the state or by business. Federal infrastructure facilities that were completed and started by the state (together with business) often do not provide the declared efficiency.

A fundamental scientific problem is the development of approaches to optimizing the scheme of interaction of various stakeholders (federal, regional, local government bodies and private investors) in the implementation of interregional investment projects, taking into account the balance of interests and risks in the long term.

\section{Theoretical framework}

Consideration of the problems of spatial economic development should be linked with such theoretical concepts as the theory of economic space organization (Losch, 1959), the theory of functions and location of human settlement system (central places) (Christaller, 1933), the theory of spatial diffusion of innovations (Hägerstrand, 1985), the centre-peripheral paradigm of D. Friedman (Friedman, 1966), the theory of growth poles by F. Perroux (Perroux, 1954); concept of social determination of market relations by K. Polanyi (Polanyi, 1944), paradigms of "basic cities" and "market rooting” (Engelen et al., 2017; Thompson et al., 2020). Important in studying the prospects for spatial economic development are the work of the Soviet economists-geographers N.N. Baransky, N.N. Kolosovsky, M.K. Bandman et al. on the theoretical issues of the location of production and the creation of territorial production complexes (Bandman, 1990; Bandman et al., 2000); as well as the economists N.N. Nekrasov, A.G. Granberg (Granberg, 1985) et al. on the methodological issues of regional economics, the research by the Council for the Study of Productive Forces, the Institute of Regional Economy Problems of the Russian Academy of Sciences, the Institute of Economics of the Ural Branch of the Russian Academy of Sciences, the Institute of Economics and Industrial Engineering of the SB RAS (Resursnye regiony..., 2017), etc.

In theoretical terms, we should note a certain disunity of research on the above range of issues. The problem of integration and development of districts and regions of Siberia on the basis of the formation of interregional and interbranch industrial clusters has not been raised in the scientific community of the country as a big all-Siberian and even all-Russian problem in the last decades. Therefore, many valuable scientific data and results related to this problem are still in a scattered and non-systematic form, do not add up to a single whole picture, explained by a logical and harmonious theory and supported by quantitative estimates.

Practical actions undertaken at the level of individual districts are not sufficiently systemic; as a rule, they solve narrow sectoral prob- 
lems and local regional problems, seldom take into account the multiplicative general economic and social effect, which manifests itself at the level of inter-sectoral and inter-regional cooperation.

\section{Problem statement}

The Angara-Yenisei macroregion (AYR) ${ }^{1}$ is a typical Siberian region of the resource type. By now, a certain system of territorial-production clusters (TPC) has already partially formed here, and its development can be predicted. Along with the developed (Central-Krasnoyarsk, Irkutsk-Cheremkhovsky TPC), this system highlights developing, emerging and projected (conceptual) territorial clusters, mainly specializing in the extraction, production and deep processing of fuel and energy, mineral raw materials and forest resources (Shishatsky, 2014).

The most promising among them are the Sayan (Khakass-Minusinsky and Kyzyl-Kuraginsky) TPCs located in the southern part of the Angara-Yenisei macro region ${ }^{2}$ (Table 1).

Large infrastructure projects can be the integrating basis for the formation of the Sayan territorial-production clusters, namely the Elegest-Kyzyl-Kuragino railway (from Kyzyl the road can be extended to Western Mongolia to Urumchi and further to China - Pakistan, India), an increased throughput of the Artyshta-Mezhdurechensk- Tayshet section and the creation of transport infrastructure for the development of coal deposits in Khakassia, the transboundary automobile corridor Krasnoyarsk-Abakan-Kyzyl-Khandagayty-Ulangom-Khovd-Urumchi, the Abakan-Biysk road.

\footnotetext{
1 The Angara-Yenisei macroregion includes Krasnoyarsk Krai, the Irkutsk Region, the Khakasia Republic and the Republic of Tuva.

2 The southern regions of the Angara-Yenisei macroregion include the southern macroregion of Krasnoyarsk Krai (the Minusinsk urban district and 7 municipal districts - Ermakovsky, Idrinsky, Karatuzsky, Krasnoturansky, Kuraginsky, Minusinsky, Shushensky), the Republic of Khakassia and the Republic of Tuva. The territory of this area is about 305.1 thousand $\mathrm{km} 2$ ( $1.8 \%, 7.0 \%$ and $9.0 \%$ of the area of the territory of the Russian Federation, Siberian Federal District and the Angara-Yenisei macroregion, respectively), as of 01.01.2020 about 1,091.9 thousand people lived here $(0.7 \%, 6.4 \%$ and $17.8 \%$ of the population of the Russian Federation, the Siberian Federal District and the Angara-Yenisei macroregion, respectively).
}

The implementation of these unique integrating projects will increase the transport accessibility and commercial attractiveness of the development of fuel and energy (oil, gas, coal) and various mineral resources (copper and nickel ores, gold, rare earths, iron ores and other deposits) located in the zone of influence of transport and energy infrastructure (Table 2).

Favourable factors for the formation and implementation of a package of large investment projects of the Sayan TPC are:

- the presence of the largest companies in the mineral resources sector in the region, which can potentially become leaders in cluster formations and determine the long-term strategy of the regional economic system (Norilsk Nickel, Rusal, SUEK, etc.);

- the interest of the state in the implementation of the complex investment project "Yenisey Siberia";

- the interest of the regions (Krasnoyarsk Krai, the Republic of Tuva and the Republic of Khakassia) in the integration of the socio-economic development of their territories ${ }^{4}$;

- the creation of an interregional Yenisey Siberia Development Corporation ${ }^{5}$.

The implementation of large-scale investment projects is characterized by a high share of innovation and development costs and high investment risks. These circumstances expand and complicate the problems of project implementation and assessment of their effectiveness.

A scientifically grounded systematic approach to assessing the conditions for the implementation of each specific project for the formation of $\mathrm{T}$ $\mathrm{PC}$ is required, taking into account the specificity of natural, economic, social and environ-

\footnotetext{
3 Order of the Government of the Russian Federation of March 29, 2019 \# 571-p "On the list of investment projects implemented as part of Yenisey Siberia complex investment project".

4 Agreement on cooperation between Krasnoyarsk Krai, the Republic of Tuva, the Republic of Khakassia on the implementation of the Yenisey Siberia project (13.04.2018, Krasnoyarsk). Available at: http://www.krskstate.ru/dat/bin/docs attach/78909_soglaqenie.pdf

5 Official website of the Yenisey Siberia Development Corporation. Available at: https://en.ensib.ru/about/corporation
} 
Table 1. Brief description of the Sayan TPC of the Angara-Yenisei macroregion

\begin{tabular}{|l|l|l|l|l|}
\hline \multicolumn{1}{|c|}{ Clusters } & $\begin{array}{l}\text { Development } \\
\text { level }\end{array}$ & \multicolumn{1}{|c|}{$\begin{array}{c}\text { Core of production } \\
\text { specialization }\end{array}$} & $\begin{array}{c}\text { Localization } \\
\text { level }\end{array}$ & \multicolumn{1}{c|}{ Territorial composition } \\
\hline $\begin{array}{l}\text { Khakass- } \\
\text { Minusinsky }\end{array}$ & Developing & $\begin{array}{l}\text { Aluminium industry, hy- } \\
\text { dropower, agro-industrial } \\
\text { complex, coal industry, } \\
\text { mechanical engineering }\end{array}$ & Interregional & $\begin{array}{l}\text { Republic of Khakassia, Krasno- } \\
\text { yarsk Krai (Minusinsk, Minusin- } \\
\text { sky and Shushensky regions) }\end{array}$ \\
\hline $\begin{array}{l}\text { Kyzyl- } \\
\text { Kuraginsky }\end{array}$ & $\begin{array}{l}\text { Forming } \\
\text { projected) }\end{array}$ & $\begin{array}{l}\text { Coal industry, polym- } \\
\text { etallic ores, iron ore, } \\
\text { gold, forest industry }\end{array}$ & $\begin{array}{l}\text { Interregional } \\
\text { (international) }\end{array}$ & $\begin{array}{l}\text { Republic of Tuva, Krasnoyarsk } \\
\text { Krai (Kuraginsky, Ermakovsky, } \\
\text { Krasnoturansky, Karatuzsky, Id- } \\
\text { rinsky Districts), Mongolia, China }\end{array}$ \\
\hline
\end{tabular}

Table 2. Projects for the development of mineral deposits located in the area of the Sayan TPC

\begin{tabular}{|c|c|c|c|c|c|}
\hline \multirow{2}{*}{ Project Title } & \multirow{2}{*}{ Geographic location } & \multirow{2}{*}{$\begin{array}{l}\text { Project capacity } \\
\text { of the primary } \\
\text { production }\end{array}$} & \multicolumn{3}{|c|}{$\begin{array}{c}\text { Investment costs } \\
\text { (billion roubles), in prices of } 2018\end{array}$} \\
\hline & & & Total & $\begin{array}{l}\text { primary } \\
\text { production }\end{array}$ & $\begin{array}{l}\text { local infra- } \\
\text { structure }\end{array}$ \\
\hline Elegestsky MPP & $\begin{array}{l}\text { Chedi-Khol kozhuun } \\
\text { (Republic of Tuva) }\end{array}$ & $\begin{array}{l}15 \text { million tons of } \\
\text { coal concentrate }\end{array}$ & 60,9 & 41,9 & 19,0 \\
\hline Mezhegeysky MPP & $\begin{array}{l}\text { Tandinsky kozhuun } \\
\text { (Republic of Tuva) }\end{array}$ & $\begin{array}{l}5.1 \text { million tons of } \\
\text { coal concentrate }\end{array}$ & 22,7 & 15,5 & 7,2 \\
\hline Beysky coal cluster & $\begin{array}{l}\text { Altai, Beysky } \\
\text { districts (Republic } \\
\text { of Khakassia) }\end{array}$ & $\begin{array}{l}17.05 \text { million tons } \\
\text { of coking coal }\end{array}$ & 71,9 & 47,5 & 24,4 \\
\hline Ak-Sugsky MPP & $\begin{array}{l}\text { Todzhinsky } \\
\text { kozhuun (Re- } \\
\text { public of Tuva) }\end{array}$ & $\begin{array}{l}456 \text { thousand tons } \\
\text { of copper-molyb- } \\
\text { denum concentrate }\end{array}$ & 93,4 & 56,6 & 36,8 \\
\hline $\begin{array}{l}\text { Kuraginsky iron ore cluster } \\
\text { (Terekhovskoe, Tabratskoe, } \\
\text { Khabalykskoe deposits) }\end{array}$ & $\begin{array}{l}\text { Kuraginsky District } \\
\text { (Krasnoyarsk Krai) }\end{array}$ & $\begin{array}{l}3445 \text { thousand } \\
\text { tons of salable iron } \\
\text { ore concentrate } \\
\text { ( } 65 \% \text { of iron) }\end{array}$ & 61,0 & 39,5 & 21,5 \\
\hline $\begin{array}{l}\text { Lysansky } \\
\text { MPP }\end{array}$ & $\begin{array}{l}\text { Kuraginsky District } \\
\text { (Krasnoyarsk Krai) }\end{array}$ & $\begin{array}{l}744 \text { thousand } \\
\text { tons of titani- } \\
\text { um-magnesium } \\
\text { concentrate }\end{array}$ & 12,6 & 6,1 & 6,5 \\
\hline Artemovsk gold ore cluster & $\begin{array}{l}\text { Kuraginsky and } \\
\text { Karatuzsky districts } \\
\text { (Krasnoyarsk Krai) }\end{array}$ & $4500 \mathrm{~kg}$ of gold & 8,1 & 3,2 & 4,9 \\
\hline Tuva gold ore cluster & $\begin{array}{l}\text { Kaa-Khem kozhuun } \\
\text { (Republic of Tuva) }\end{array}$ & $2400 \mathrm{~kg}$ of gold & 5,7 & 2,2 & 3,5 \\
\hline Total & & & 336,3 & 212,5 & 123,8 \\
\hline \multicolumn{6}{|l|}{ including } \\
\hline Republic of Tuva & & & 182,8 & 116,2 & 66,5 \\
\hline Republic of Khakassia & & & 71,9 & 47,5 & 24,4 \\
\hline $\begin{array}{l}\text { Southern regions of the } \\
\text { Krasnoyarsk Krai }\end{array}$ & & & 81,7 & 48,8 & 32,9 \\
\hline
\end{tabular}


mental conditions, as well as the characteristics of the assets of private companies and their strategic interests in the world and Russian markets.

\section{Methods}

One of the significant institutional innovations of the Strategy of Spatial Development of the Russian Federation until $2025^{6}$ was the introduction of the category of so-called centres for prospective economic growth and the approval of the principle of priority development for individual territories as one of the important instruments of state policy of regional development. The practical implementation of this principle allows developing new territories as quickly and efficiently as possible, equalizing interregional economic disproportions, consistently ensuring the interests of the country's national and economic security.

However, in practice, any priority is a rather contradictory instrument of the state's socio-economic policy. The main problem here is that the implementation of this or that form of priority may conflict with other tasks of the socio-economic development of the country and its regions.

Within the framework of the currently widespread "project approach", when the implementation of individual investment projects is considered, their possible impact on the socio-economic development of the territory is not taken into account. The limitations of this approach can be revealed only after a comprehensive consideration of the implementation of the largest investment projects in a particular territory. In addition to the direct impact, it is important to consider the effects of the multiplicative impact of investment projects on the territory, confirming their status as development poles in the region. To fulfil the task of territorial development, an investment project must have a systemic impact on the surrounding socio-economic environment, that is, in addition to financial effects, generate additional socio-demographic and infrastructural effects.

\footnotetext{
6 Order of the Government of the Russian Federation of February 13, 2019 \# 207-p "On approval of the Strategy for the spatial development of the Russian Federation for the period up to 2025 ".
}

Figure 1 shows schematically three possible scenarios for the implementation of a large investment project: 1) spot implementation; 2) the spread of investments in the periphery; 3) stimulation of local economic growth.

The implementation of the investment project according to the scenario "stimulation of local economic growth" not only creates additional jobs, but also produces additional socio-demographic effects: arrangement of the habitat for those employed in the new production; stimulates the attraction and / or preservation of the population in a given territory, including by changing the settlement system.

As part of the infrastructural impact of the project, the infrastructure is being formed or improved on the territory, which is used in the main production, as well as contributes to the development of other types of economic activity and can perform social functions, improving the quality of life in the region.

The general scheme for assessing the scenarios of the socio-economic development of the macroregion with the inclusion of a model block for the development of territorial-production clusters and a block for assessing the social and environmental consequences of the implementation of large investment projects is shown in Fig. 2 and 3.

\section{Discussion}

At present, the Republic of Tuva and the southern group of Krasnoyarsk Krai districts belong to depressed territories. The Republic of Khakassia is characterized by a higher (but also insufficient) level of economic development - the per capita GRP income is $25 \%$ lower than the national average and $10 \%$ lower than the average Siberian level (Table 3).

The growth rates of the most important indicators remained very low over the past years (2010-2018). The results of development in the southern regions of Krasnoyarsk Krai were especially depressing - depopulation, a decrease in the level of income of the population and the cessation of economic growth (Table 4).

The analysis of large investment projects planned for implementation, which form the basis of the formed TPC (Elegestsky MPP, Beysky coal cluster, Ak-Sugsky MPP, Kuragin- 


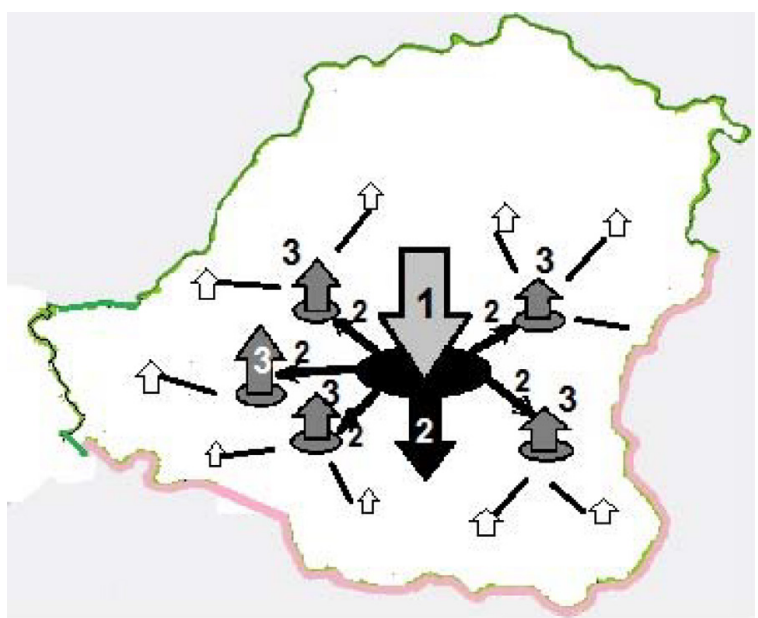

Fig. 1. Scheme of the impact of a large investment project on territorial development according to three possible scenarios for the implementation of a large investment project:

1) spot implementation; 2) the spread of investments in the periphery; 3) stimulation of local economic growth

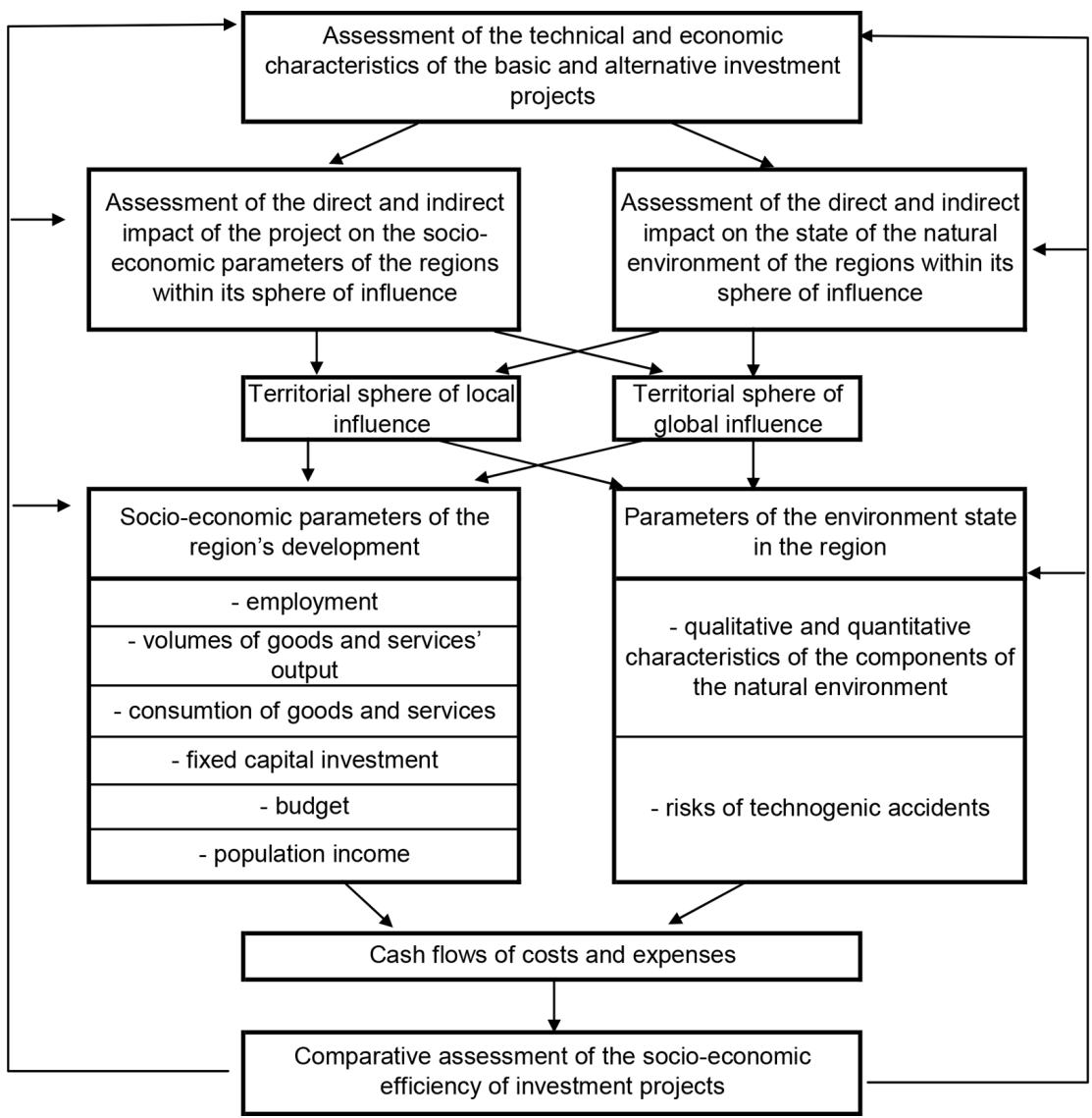

Fig. 2. Scheme of a comprehensive assessment of the socio-economic and environmental consequences of the implementation of large investment projects 


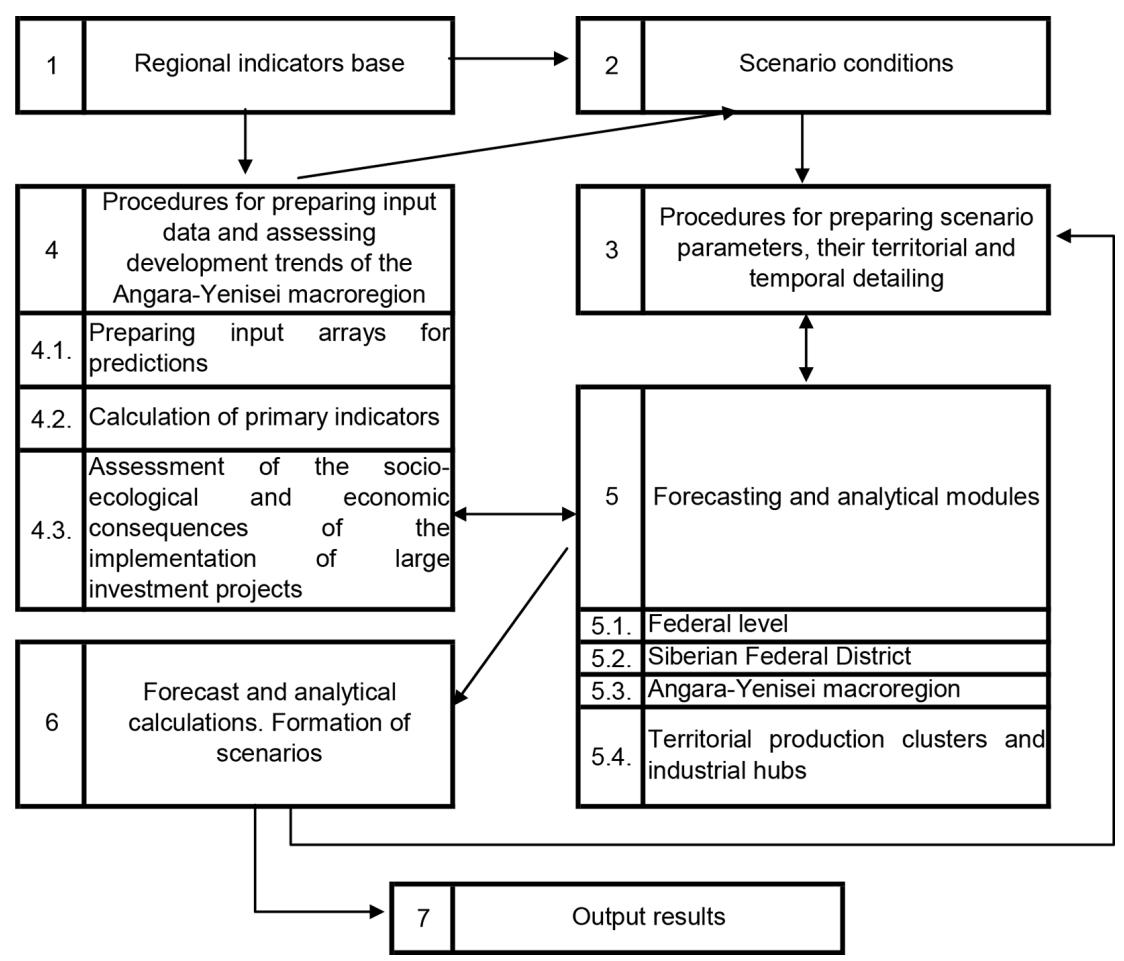

Fig. 3. Scheme for assessing scenarios of socio-economic development of a macroregion with the inclusion of a model block for the development of territorial-production clusters

Table 3. Ratio of per capita GRP in the regions of the Sayan economic centre with the average Russian and Siberian indicators (2018)

\begin{tabular}{|l|c|c|}
\hline & $\begin{array}{c}\text { The national per capita GRP } \\
\text { in the Russian Federation }=100 \%\end{array}$ & $\begin{array}{c}\text { The Siberian Federal District } \\
\text { per capita GRP }=100 \%\end{array}$ \\
\hline Southern regions of Krasnoyarsk Krai & $48,8 \%$ & $58,2 \%$ \\
\hline Republic of Tuva & $36,8 \%$ & $43,9 \%$ \\
\hline Republic of Khakassia & $75,7 \%$ & $90,5 \%$ \\
\hline
\end{tabular}

sky iron ore cluster, Lysansky MPP, etc.), made it possible to assess their impact on the level of the socio-economic development of Sayan Economic Centre's territories. The projects being implemented have a certain positive impact on the territory - they form a new spatial configuration of economic growth, shifting the overall economic potential from the centre to peripheral areas. After launching the planned enterprises, this shift will be expressed mainly in an increase in the volume of the gross regional product and revenues of local budgets. The impact on the settlement system will be less pronounced, since the involvement of shift workers in the projects and the mono-profile of the accompanying settlements will not contribute to the creation of new industries in them, and, therefore, to the attraction of a significant number of the population.

Raw materials orientation of production within the framework of projects for the development of mineral resources has a limited effect on the development of the territory after the completion of construction. This effect is concentrated mainly in the service industries: 
Elena A. Bryukhanova, Valery S. Efimov... Research on the Issues of Economic Growth Centres' Establishment...

Table 4. Main indicators of the socio-economic development of the Sayan Economic Centre's regions in 2018

\begin{tabular}{|l|l|c|c|c|c|}
\hline \multicolumn{1}{|c|}{ Indicators } & \multicolumn{1}{|c|}{ Period } & $\begin{array}{c}\text { Southern regions of } \\
\text { Krasnoyarsk Krai }\end{array}$ & $\begin{array}{c}\text { Republic of } \\
\text { Khakassia }\end{array}$ & $\begin{array}{c}\text { Republic } \\
\text { of Tuva }\end{array}$ & Total \\
\hline \multirow{2}{*}{$\begin{array}{l}\text { Gross regional } \\
\text { product }\end{array}$} & million roubles & 84000 & 235311 & 68774 & 388085 \\
\cline { 2 - 6 } & growth, in \% by 2010 & 101,1 & 120,5 & 111,9 & 114,1 \\
\hline $\begin{array}{l}\text { Population (by the } \\
\text { end of the year) }\end{array}$ & thousand people & 231,8 & 536,2 & 324,4 & 1092,4 \\
\cline { 2 - 6 } & growth, in \% by 2010 & 93,9 & 100,6 & 105,7 & 100,5 \\
\hline Population income & $\begin{array}{l}\text { thousand roubles per } \\
\text { person per month }\end{array}$ & 14,0 & 21,6 & 15,6 & 18,2 \\
\cline { 2 - 6 } & growth, in \% by 2010 & 93,8 & 110,5 & 92,7 & 102,7 \\
\hline \multirow{2}{*}{$\begin{array}{l}\text { Own budget reve- } \\
\text { nues }\end{array}$} & million roubles & 5137,6 & 30244,8 & 6944,7 & 42327,1 \\
\cline { 2 - 6 } & growth, in \% by 2010 & 102,4 & 157,5 & 121,6 & 141,4 \\
\hline
\end{tabular}

Note: the authors' assessment is based on official statistics; the dynamics of cost indicators is given in comparable prices.

Table 5. Forecast of the main indicators of the Sayan Economic Centre's regions' socio-economic development in 2019-2027 (taking into account the implementation of infrastructure development projects and mineral resources development projects), growth in 2027 compared to the level of 2018 in \% (value indicators in comparable prices)

\begin{tabular}{|l|c|c|c|c|}
\hline & $\begin{array}{c}\text { Gross Regional } \\
\text { Product }\end{array}$ & Population & $\begin{array}{c}\text { Population } \\
\text { income }\end{array}$ & $\begin{array}{c}\text { Own budget } \\
\text { revenues }\end{array}$ \\
\hline \multicolumn{5}{|c|}{ Option with limited multiplicative distribution of investments in the territory } \\
\hline Southern regions of Krasnoyarsk Krai & 119,5 & 96,2 & 103,9 & 119,2 \\
\hline Republic of Khakassia & 122,6 & 101,0 & 112,7 & 129,4 \\
\hline Republic of Tuva & 130,7 & 106,4 & 104,4 & 130,3 \\
\hline Total Option with an additional multiplier effect of the investments' distribution in the territory \\
\hline \multicolumn{7}{|c|}{123,3} & 101,6 & 109,2 & 122,8 \\
\hline Southern regions of Krasnoyarsk Krai & 125,5 & 100,2 & 115,8 & 138,7 \\
\hline Republic of Khakassia & 132,3 & 102,8 & 111,6 & 139,8 \\
\hline Republic of Tuva & 137,9 & 107,3 & 113,6 & 137,0 \\
\hline Total
\end{tabular}

energy, communications, to some extent - in transport.

The development of integrating and complementary industries and types of economic activity (agro-industrial and forestry complex, tourism and recreation, processing of raw materials, mechanical engineering, services in border areas) can significantly improve the indicators of regional development (Table 5).

\section{Conclusion}

1. The assumed formation of new economic centres in the conditions of compression of intensive economic activity contributes to the development of territorial structures of the Angara-Yenisei macroregion, but this development is of an extensive nature. The new centres of mining and industrial specialization will depend on the conjuncture of the world raw material markets and will not be able to flexibly integrate into the existing system of production and settlement. 
2. The analysis of the impact of large investment projects on the socio-economic development of the Sayan Economic Centre as a supposed growth pole shows their limited effect on the diffusion of investments and the revitalization of economic activity.

3. A significant impact on the development of the social and industrial infrastructure of the entire region and the intensification of local production activities are exerted by projects for the development of agro-industrial production, tourism, and services in the border areas. It is these projects that should receive government support in the formation of promising growth centres in the Angara-Yenisei macroregion (The Sayan centre).

4. The project approach aimed at creating growth points in the mineral and raw materials sector should be complemented by measures related to the systemic development of infra- structure, stimulating small and medium-sized businesses, and developing all aspects of the population's life support. Many of these measures lie in the institutional sphere (changes in taxation and tax distribution systems, the return of a number of environmental management powers to the regional level, etc.).

5 . It is necessary to change the very system of planning economic development: the strategy of forming centres of economic growth should not be a "patchwork" made of large public-private investment projects and scattered state investments in point infrastructure objects. The set of measures of the strategy should proceed from a systemic vision of the socio-economic situation in spatial terms and the expected dynamics of its development. The strategy should include the necessary additions to the proposed large investment projects, ensure the creation of the missing elements of the

territorial organization, capable of enhancing the positive effects of projects on the territory and smoothing out the negative aspects of their implementation.

\section{References}

Bandman, M.K. (1990). Territorial'no-proizvodstvennye kompleksy: opyt i problemy formirovaniia [Territorial and production complexes: experience and problems of formation]. Leningrad, Nauka, $214 \mathrm{p}$.

Bandman, M.K., Vorob'yova, V.V., Esikova, T.N., Ionova, V.D., Malinovskaya, M.A., Malov, V.YU., Yablochnikova, Ya.T. (2000). Metodicheskie rekomendatsii po vyiavleniiu vnutriregional'noi asimmetrii v sub"ektakh federatsii s tsel'iu opredeleniia putei sokrashcheniia ee v ramkakh gosudarstvennoi regional'noi ekonomicheskoi politiki [Methodical recommendations about identification of intraregional asymmetry in territorial subjects of the federation for the purpose of defining the ways of its reduction within the state regional economic policy]. Novosibirsk, IEOPP SO RAN, $71 \mathrm{p}$.

Christaller, W. (1933). The central places in Süddeutschland: an ökonomisch geographic investigation über the Gesotzmässigkeit of the spreading and development of the settlements with städtischen functions [Die zentralen Orte in Süddeutschland. Eine ökonomisch-geographische Untersuchung über die Gesetzmäßigkeit der Verbreitung und Entwicklung der Siedlungen mit städtischer Funktion].

Engelen, E., Julie Froud, J., Johal, S., Salento, A., Williams, K., (2017). The grounded city: from competitivity to the foundational economy. In Cambridge Journal of Regions, Economy and Society, 10, 407423. DOI:10.1093/cjres/rsx016.

Friedman, J. (1966). Regional Development Policy: A Case Study of Venezuela. MIT Press, 279 p.

Granberg, A.G. (1985). Ekonomika Sibiri v razreze shirotnykh zon [Economy of Siberia in view of width zones]. Novosibirsk, Nauka, $255 \mathrm{p}$.

Hägerstrand, T. (1985). Time-Geography: Focus on the Corporeality of Man, Society and Environment, In the Science and Praxis of Complexity. The United Nations University, 193-216.

Losch, A. (1959). Geograficheskoe razmeshchenie hoziaistva [The geographic arrangement of econo$m y$ ]. Moscow, Izd-vo inostr. lit., 455 p.

Perroux, F. (1954). Europe without shores [L'Europe sans ravages]. Grenoble: Presses universitaires de Grenoble, 859 p. 
Polanyi, K. (1944). The great transformation. N.Y.: Farrar \& Rinehart, 305 p.

Resursnye regiony Rossii v «novoi real'nosti» [Resource regions of Russia in the "new reality"] (2017). Novosibirsk, Izd-vo IEOPP SO RAN, 308 p.

Shishatsky, N.G. (2014). Integratsionnye faktory osvoeniia syr'evykh resursov Angara-Eniseiskogo regiona [Integration factors of development of the Angara-Yenisei region resources]. In Rossiiskii ekonomicheskii internet-zhurnal, 4 (01.10.2014-31.12.2014).

Thompson, M., Nowak, V., Southern, A., Davies, J., Furmedge, P. (2020). Re-grounding the city with Polanyi: From urban entrepreneurialism to entrepreneurial municipalism. In EPA: Economy and Space 2020, 52(6), 1171-1194. DOI: 10.1177/0308518X19899698

\title{
Исследование проблем формирования центров экономического роста в южных районах Ангаро-Енисейского макрорегиона
}

\author{
${ }^{a}$ Институт экономики и организации \\ промышиленного производства СО РАН \\ Российская Федерачия, Красноярск \\ ${ }^{6}$ Сибирский федеральный университет \\ Российская Федераиия, Красноярск
}

Е.А.Брюханова ${ }^{a}$ В.С. Ефимов ${ }^{6}$, Н.Г. Шишацкийа

\begin{abstract}
Аннотация. В статье рассмотрены характерные особенности и условия реализации крупных инвестиционных проектов и возможности формирования на этой основе региональных центров перспективного экономического роста. Проведен анализ крупных инвестиционных проектов, направленных на развитие минеральносырьевого сектора в южных районах Ангаро-Енисейского макрорегиона. Получена оценка воздействия проектов на показатели социально-экономического развития территорий. Показано, что проектный подход, нацеленный на реализацию отдельных инвестиционных проектов и создание точек роста в минерально-сырьевой сфере, должен дополняться мерами, направленными на развитие территориальной инфраструктуры, стимулирование малого и среднего бизнеса, улучшение всех сторон жизнеобеспечения населения.
\end{abstract}

Ключевые слова: Ангаро-Енисейский макрорегион, центр перспективного экономического роста, территориально-производственные кластеры, крупный инвестиционный проект, комплексное социально-экономическое развитие.

Исследование выполнено при финансовой поддержке Российского фонда фундаментальных исследований, Правительства Красноярского края, Красноярского краевого фонда науки в рамках научного проекта № 19-410-240003 «Обоснование приоритетов опережающего социально-экономического развития регионов Енисейской Сибири (на примере южных территорий Красноярского края, Республики Хакасия и Республики Тыва)».

Научная специальность: 08.00.00 — экономические науки. 